\title{
FAILED FRIENDSHIP, FORGOTTEN GENEALOGIES: \\ SIMONE DE BEAUVOIR AND LUCE IRIGARAY
}

Luce Irigaray opens je ,tu, nous: Toward a Culture of Difference with "A Personal Note." It begins:

What woman has not read The Second Sex? What woman hasn't found it inspiring? Hasn't as a result, perhaps, become a feminist? Simone de Beauvoir was indeed one of the first women in this century to remind us of the extent of women's exploitation and to encourage every woman who had the good fortune to come across her book to feel less isolated and more certain about being oppressed or letting herself be taken in ... Although I read The Second Sex, I was never close to Simone de Beauvoir. Why?... There are important differences between our positions which as far as friendship and mutual assistance goes, I had hoped could be overcome. In actual fact they were not... What can we make then of this distance kept up between two women who could, indeed should have worked together? (9-11)

Probing Beauvoir's "reticence," Irigaray traces it to two causes. First, she finds that Beauvoir could not accept her commitment to psychoanalysis - could not endure her use of psychoanalysis in understanding the sexual determination of the development and history of consciousness. Second, she determines that Beauvoir could not accept the idea that the quest for equality is an insufficient ground for/of women's liberation, and could not, therefore, support the advocacy of sexed rights.

Neither I nor Irigaray can be sure that this explains the matter. We cannot know why Beauvoir never responded when Irigaray sent her a copy of Speculum. We can only guess at the reasons for Beauvoir's silence. Like Irigaray, I regret the absence of friendship between these two seminal feminist thinkers; for if, as Nietzsche and Derrida suggest, the "best" friend is the worthy enemy, then this is a friendship that should have been. Despite Beauvoir's refusal, Irigaray ends her "Personal Note" with a gesture of friendship. Situating her work within the horizon opened by The Second Sex Irigaray writes:

To respect Simone de Beauvoir is to follow the theoretical and practical work for social justice that she carried out in her 
own way; it is to maintain the liberating horizons which she opened up for many women and men...It seems to me that her concern for and writings on this subject are a message not be forgotten.(Irigaray, je 13-14)

And yet Irigaray forgets. She turns a deaf ear to the ways in which The Second Sex calls for a transvaluation (not an eradication) of the sexual difference. She hears Beauvoir's demands for political and economic equality as a call for an androgynous future rather than as a call for a future in which sex and gender are lived differently. Not reading The Second Sex within the context of The Ethics of Ambiguity's descriptions of intentionality, Irigaray does not probe the ways in which her genealogical debt to Beauvoir goes beyond the general fact that The Second Sex opened her (our) feminist eyes. In short, because Irigaray reads Beauvoir as an uncomplicated "equality" feminist, she positions herself and Beauvoir as oppositional thinkers. I think that this is both mistaken and unfortunate because it simplifies the differences between her and Beauvoir and repeats the all too familiar philosophical gesture of negating the other.

The Second Sex is a politically liberatory and philosophically demanding text. In identifying the injustices suffered by women idealized as woman and habituated to be feminine, it alerts us to the desires that create and sustain the social, political and economic structures of patriarchy. Most importantly, in attempting to determine why it is that women, unlike other oppressed groups fail to rebel, it distinguishes the category of the Other from the category of the inessential other. The category of the Other belongs to the Hegelian dialectic of violence, recognition and reconciliation. It grounds Sartre's analysis of "The Look". It appears to be gender neutral. Beauvoir discovers the lie of the appearance. She details the ways in which the category of the other is distinctly masculine.

The category of the Other, according to Beauvoir, is a specifically patriarchal category. Only men fight to the death, demand mutual recognition, and exchange looks. Women, Beauvoir shows us, are excluded from the possibilities of rebellion, revolution or reconciliation. Barred from being the Other, they are confined to the place of the inessential other. As each other's other, men enact their desire. As men's inessential other, women reflect men's desires back to them. They may not and must not articulate a desire of their own. 
When Irigaray speaks of women as lacking a symbolic means of expressing their desire-as not (yet) existing--she is in fact echoing Beauvoir, who in the opening pages of The Second Sex wonders whether she really exists. Beauvoir introduces The Second Sex with a question. "What", she asks, "is a woman?" (xix). Within the space of a page, she determines that though it is certain that women exist, it is also clear that women's existence can only be admitted provisionally (xxi). Beauvoir is certain that women exist because she cannot doubt that she exists. She must, if she wishes to affirm her existence "first of all say: I am a woman; on this truth must be based all further discussion" (xxi, emphasis added). Her existential certainty, however, is riddled with problems. For once Beauvoir asks for a definition of woman (of herself insofar as she is first of all a woman), she discovers that so many accounts are provided (with so many being contrary to each other) that she cannot say which, if any, are real/true. Caught in the Cartesian dilemma-she is certain that she is but doubts who she is-Beauvoir cannot follow Descartes' strategy; for she acknowledges a certainty that escaped Descartes. There are two distinguishable human types: men and women. It is impossible to identify oneself as a human being without first taking one's place in the sexual register. The certainty of being sexed is inseparable from the certainty of being human. ${ }^{1}$

I read Beauvoir's affirmation of this double certainty as a claim about the human condition. Irigaray, I think, reads it as a provisional claim about patriarchal humanity, for she reads Beauvoir as intent on erasing the sexual difference. Which of us is correct is not what is at stake here however. Whether Beauvoir sees the sexual difference as part of the injustice of patriarchy, or whether she sees it as a necessary mark of our humanness, that she sees the sexual difference as a difference that marks women as (presently) absent and men as fully present situates her as a genealogical friend of Irigaray. Irigaray, however much she may respect Beauvoir, does not recognize her genealogical debt. Given what she teaches us about the ways in which patriarchy erases women's genealogies and about the ways in which this erasure is essential to the power of patriarchy, this lack of recognition is particularly troubling. The depths of this trouble may be seen if we turn to Irigaray's Ethics of Sexual Difference and her reflections on Descartes' first passion-wonder.

\footnotetext{
${ }^{1}$ For a discussion of the relationship between Descartes and Beauvoir see Simons 202 and Bauer 46-77.
} 
Irigaray opens An Ethics of Sexual Difference telling us that though some overtures have been made to the world of women, no new values have been established. Lacking these values, women's "issues" remain at the level of critical demands. As merely critical demands they are unsustainable. To have an enduring effect, women's "demands" must be seen as necessary corollaries of the values of an ethics of sexual difference. According to Irigaray, there has been a "worldwide erosion of gains won in women's struggles" because these gains are seen as political or economic expediencies rather than as ethical necessities. An Ethics of Sexual Difference draws the lines of an ethics of sexual difference and establishes the ways in which women's demands, far from being merely expedient, are necessary corollaries of this ethics.

We might, from a glance at the table of contents of An Ethics of Sexual Difference, conclude that the matter of wonder is marginal to these issues. But tables of contents can be deceiving. For if the essay on Descartes' passion of wonder, one of the shorter pieces in the volume, seems buried within the text, the passion of wonder, defined as the passion of otherness elicited by the encounter with the forever unknowable of the other sex, permeates Irigaray's discussions of the possibilities, implications and meanings of an ethics of sexual difference (Ethics 8 and 13). For Irigaray, an ethics of sexual difference is an ethics of wonder. Whether Descartes' wonder can, without appeal to Beauvoir, serve Irigaray's ethics is the matter at hand.

Descartes' wonder is not a simple passion. It is always accompanied by a mood. This mood is crucial. Whether wonder, the astonishment at the encounter with the unexpected, is accompanied by the mood of anxiety, delight, or joy determines the ways in which wonder positions itself vis-à-vis desire. It determines whether wonder will become for ethics what the cogito became for Descartes' epistemology and metaphysics, the root that nourishes everything that follows; or whether wonder's priority will be reduced to a matter of origins analogous to the priority of the child to the adult, something to be outgrown as we mature. The wonder of anxiety is quickly displaced by the desires/judgments of love and hate. The wonder of joy does not flee from itself in the rush to judgment and desire. It delights in its openness to the surprise of the other. Going through the history of philosophy, we learn to distinguish the moods of wonder. We learn how to spot the Trojan horse. 
Irigaray is, I think, correct. The ground of an ethics of sexual difference must be wonder. Descartes' wonder, however, will not direct us to this ethics. His wonder falls prey to the mood of anxiety. It fuels the economy of the same. An ethics of sexual difference needs the ground of a wonder of delight and joy. For it is only as accompanied by the mood of joy that wonder is embraced as the useless passion, a passion that is not a means to the end of desire but a delight that is an end in itself. If we need Descartes to remind us of the passion that Freud forgot, we need Beauvoir to embed this passion in its proper mood-joy.

This becomes clear if we situate Irigaray's reading of Descartes' Passions of the Soul within the context of her reading of the Meditations. In Speculum Irigaray begins reading Descartes where most interpreters begin. She takes up the question of Descartes' doubt. Descartes goes to great pains to distinguish the criteria of falsity from the criteria of doubtfulness. Irigaray is not interested in this sleight of hand. Whether we declare something to be false or dubious we are engaged in an act of negation. We say "no" to it. We disengage from it. We withhold our attention. We become indifferent (Irigaray, Speculum 182). Further, as a Cartesian doubter, I am motivated by the desire for certainty. I say "no" in order to be able to say "yes" and I will only say "yes" if it is impossible to say "no." First philosophy as grounded in the desire for certainty; the desire for certainty sustained by the no; the cogito as a refusal. This is Irigaray's Descartes.

Arriving at this Descartes Irigaray probes Descartes' refusal. An easy query from one point of view. Certainly no secret to any reader of the Meditations. Descartes refuses the uncertainties of sense experience. He has, Irigaray reminds us, discovered the tricks of the eye. He is an expert in optics. As an expert he is also, however, duped. Understanding mirrors, he is innocent when it comes to the illusions of the mirror stage. Fleeing the (il)logic of the senses, he gets caught in the logic of the specular imaginary. The cogito is an ego-imago. Descartes, Irigaray tells us, knows that the world always appears upside down and is therefore subject to doubt. He refuses, however, to consider that the subject is a reversal of itself because he desires union "with an image in a mirror" (Irigaray, Speculum 189).

Reading Descartes through Irigaray comes to this: If we begin by saying "no," the certainty we arrive at is the certainty of the imaginary. The desire for certainty, specifically the desire for the 
certainty of self identity must be understood as the desire for an imaginary wholeness/ autonomy. The doubt, the no that makes selfaffirmation possible, must also be understood as a refusal to acknowledge our relationship to the (m)other. The method of doubt, Irigaray tells us, is "a refusal of anything not his same self [and therefore] ... a refusal of all beginnings" (Irigaray, Speculum 183). To doubt is to refuse the "precariousness of existence ... the chain of relationships, the cord ... the mysteries of conception" (Irigaray, Speculum 182). Lured by the seduction of the mirror, pursuing the desire to be himself, Descartes forgets the mother who kindles his desire. He forgets that he wants to be himself in order to establish himself as the One the mother desires. Finding himself in a double bind he cuts the cord; for if he acknowledges the mother then he cannot be himself (autonomous), but if he is not himself (autonomous) he cannot assure himself that he is the One of the mother's desire. Ah, perhaps Descartes (and we) can have it all? Perhaps he (and we) can cure himself of the precariousness of existence by erasing the mysteries of conception? Perhaps we can both be ourselves as autonomous, the One that is desired, and be the one who legitimates our desire? Perhaps we can escape the anxiety of finitude by giving birth to ourselves?

As I read Irigaray's account of the cogito, I am struck by the ways in which the refusal of the (m)other is also and necessarily a repudiation of wonder. We are witnesses to a double murder. We are also, it seems, confronted by the radical incompatibility between Descartes' first methodological principle - the doubt that says "no"and his first passion-the wonder that says "yes." Reading Descartes" essay on the passions, however, we discover that for Descartes it is not a matter of choosing between the no of first philosophy and the yes of passion, but a matter of proper subordination. The yes of the first passion will be appropriated by the no. The mood of anxiety will direct the processes of sublimation. The first passion will disappear into Oedipal desire.

If we return Irigaray's reading of Descartes' cogito to Descartes'discussion of wonder, we discover the link between saying "no," the drive for autonomy, and the denigration of wonder. Descartes describes wonder as "a sudden surprise of the soul" and as a prejudgmental receptive passivity (Descartes LXX). Unlike our other passions, which as grounded in the judgments good and bad move us to either pursue what we believe will benefit us, or avoid things we think will harm us (Descartes LVII), wonder, not knowing the categories 
good and bad, neither moves to appropriate nor dismiss the object before it. Taken up with the categories rare and extraordinary wonder considers objects in their own uniqueness rather than for their effects on us (Descartes LXX). As synonymous with surprise with regard to both the new of the unknown and the unexpected of what we already know, the uniqueness of wonder lies in the fact that insofar as we are taken by surprise we are unable to calculate and must therefore simply attend to the givenness of the phenomena. Wonder says pay attention. First philosophy says withdraw, become indifferent, disengage from the surprises of the world. First philosophy, in refusing the passivity of the senses, sacrifices wonder to the desire for certainty.

The propriety of this sacrifice is never questioned. It is sometimes described as a natural process, analogous to the hardening of the soles of our feet; and sometimes identified with the discipline of science. But however it is described, Descartes is adamant, we must outgrow the passion of wonder. Descartes' assessment of wonder, his account of its role in our lives is summed up as follows: “. . . although it is good to be born with some inclination toward this passion [of wonder], because it disposes us toward the acquisition of the sciences, we must at the same time try to free ourselves from it as much as possible" (Descartes LXXVI).

Irigaray tells us that Descartes' wonder is the appetite for knowledge (Irigaray, Ethics 78). Descartes identifies wonder as disposing us toward the acquisition of the sciences. It stimulates the appetite for knowledge. Once stimulated, however, the appetite no longer needs wonder. It can and must dispense with the passion that triggered its desire.

As wonder is said to dispose us toward science, science is charged with protecting us from the surprises of wonder. Its job is to render the unfamiliar familiar. Descartes never values wonder for itself; for left to itself, wonder threatens us with the disease of blind curiosity. What Irigaray asks us to cultivate, wonder without stopping, Descartes insists we cure (Irigaray, Ethics 81 ). Instead of clearly praising wonder for bringing that which is unique to our attention, Descartes is ambiguous about the value of wonder. Ultimately he identifies it as a difficult passion requiring the discipline of science. Science, however, may not be enough to save us from the disease of wonder-blind curiosity. Self-discipline is also required. We must accustom ourselves to turn away from unworthy novelties. 
I begin to hear echoes of the method of doubt- - the withdrawal that says "no." I read Descartes'definition of blind curiosity: "to seek out things that are rare solely to wonder at them and not for the purpose of really knowing them." I read his descriptions of the two symptoms of this disease: (one) "[becoming] so given over to wonder that things of no importance are no less capable of asserting their attention than those whose investigation is more useful"; and (two) " a custom which disposes the soul ... to pause over all ... objects which present themselves provided that they appear to it to be ever so little new" (Descartes LXXVIII). I remember the definition of wonder as synonymous with surprise, and I hear anxiety. I hear a certain fear of freedoms that escape our control. If all the subsequent passions stem from our seeing objects (first brought to our attention by wonder) as free agents which can either bring us good or harm (Descartes LVLVI); if the point of science is to give us a handle on these free agents, then wonder-the receptive recognition of these unanticipated freedoms- throws us into the contingencies of our existence. The extent to which we can be surprised marks the limits of our power. Within the context of Descartes' logic (the logic of Oedipus), wonder means vulnerable. Surprises make us anxious. As anxious we move to close ourselves off from the threat of the unexpected. With the help of mathematics and reason, we create an ordered home. We solve rather than take delight in riddles. We keep the unheimlich at bay.

Descartes' anxiety about wonder goes further. When Descartes attends to the passions of joy, love, delight, fear, despair, indignation, or terror, the latter passions, fear indignation and terror are either directly correlated with wonder or described in language used to identify wonder. Joy and love are never associated with wonder. Delight sometimes appears to be aligned with wonder and sometimes not.

Minding the gap between Descartes'discussions of delight and trying to understand why Descartes associates fear but not delight with wonder, we see that wonder, the passion that precedes desire, cannot/will not become the passion that informs desire, as long as the strange is experienced as threatening rather than beautiful and difference is identified with the experience of lack. We see how much remains to be done before we can appropriate Descartes' wonder for an ethics of sexual difference. We see why Irigaray needs to remember Beauvoir. An ethics of sexual difference, grounded as it must be in wonder, will come to nothing if it does not attend to and find an 
antidote for the ways wonder becomes Cartesian wonder, appropriated by the desire for knowledge/power and caught up with the experiences of fear, indignation, cowardice, and terror.

In his discussion of wonder, Descartes argues that wonder, insofar as it attends to worthy new and unexpected phenomena, is the source of science. He warns us that becoming enamored with novelty per se is ultimately unproductive. But once he treats the passions of fear, indignation and terror we discover that surprises are not always welcome. Now we learn that the unexpected is experienced as dangerous. Fear, not wonder is now identified as our response to the strange/stranger (Descartes CLXXVI). Further, fear or terror, which he describes as a "coldness [and] also a perturbation and astonishment of the soul which takes from it the power of resisting the evils which it thinks lie at hand", is identified as a source of cowardice (Descartes CLXXIV). To avoid cowardice, we must, it seems, protect ourselves from the astonishment that causes fear. The best defense? "Nothing," Descartes tells us, is "better for getting rid of [fear] than to use premeditation to prepare oneself for all eventualities" (Descartes CLXXVI).

In drawing our attention to the new and unique wonder triggers our drive for knowledge. To know a thing is to understand its power to benefit or harm us. Such understanding puts it under our power. When knowledge fails us, however, we are reminded of the limits of our sovereignty. That which surprises us also marks us as vulnerable. Far from taking delight in the novelty before us, we become indignant. In Descartes' words:

we usually suppose that all things will be done in the manner we judge they ought to be done, that is, in the way we esteem to be good; that is why when it happens otherwise it surprises us and we wonder at it. (Descartes CXCVII)

That which is strange surprises us. We may, according to Descartes, respond to the surprise of the unexpected with wonder which leads us to science, or fear which makes us cowards. There is also, he notes, a third possibility, delight; further, there are two modes of delight. The first is associated with love, the second with the contemplation of beauty. The first concerns the sexual difference. Irigaray notes that Descartes does not situate the sexual difference at the site of wonder. I note that he situates it here, at love: delight is elicited 
by "the difference of sex which nature has placed in men ... [which] bring[s] it to pass that at a certain age and in a certain time they consider themselves defective as though they were but the half of a whole of which the individual of the other sex should be the other half. In this way the acquisition of this half is confusedly represented by nature as the greatest of all imaginable goods" (Descartes XC). This description of delight is particularly striking given that Descartes also tells us that we take delight in encountering the "perfection we imagine in a person whom we think may become another self" (Descartes XC). We cannot, it seems, simply delight in the perfection of the other as another self without seeing it as an indictment of our lack and without loving it, i.e. moving to acquire it for ourselves. The sexual difference, here, is a stranger to the passion of wonder. Delight, love and joy are part of the ethics of calculation. They concern the judgments good and bad. Associating delight with love by defining delight as "the enjoyment of that which gives pleasure as the greatest part of all the good things which pertain to man" (Descartes XC), and associating both love and delight with joy, which he defines as "the belief that we have of possessing some good" (Descartes XCII), Descartes severs delight from wonder. Under the aegis of love, the prejudgmental yes of wonder is taken up in the dialectic of lack and becomes the yes of appropriation.

There is, however, a discussion of delight in Part Three of Descartes' Passions where delight, like wonder, is distinguished from judgments concerning good and bad, from love, the desire to possess the good, and from joy, the belief that what we possess is good (Descartes LXXXVI, LXI). Here, delight is described as "'love' for beautiful things" (Descartes LXXXV), but is said to not really be love because it is not a desire. Unlike the discussions of fear, where the link is made to wonder, here no such link is noticed. Has Descartes forgotten that what distinguishes wonder from the other passions is that, like this delight described as 'love' of the beautiful, wonder is a mode of receptivity rather than desire? In not making the connection between this delight and wonder Descartes tells us that his wonder is a stranger to delight. This estrangement is crucial. As an experience of surprise and novelty but not delight, Descartes' wonder cannot contest the desires of calculation, control and possession. It cannot become the ground of an ethics of sexual difference. 


\section{The (Re)turn to Wonder-Simone de Beauvoir}

The philosophical beginning that says "no" is grounded in the desire for certainty. The passionate beginning that says "yes" is not yet inscribed in the field of desire. By estranging wonder from delight and reducing it to a necessary preliminary for science, by focusing on the causes of wonder (innocence, curiosity, surprises), and by attending to the mechanics of wonder (passivity of the senses), Descartes does not probe the meaning of wonder as a receptive, non-judgmental mode of attention. Aligning ethics with the judgments good and evil and identifying the birth of desire with these judgments, Descartes consigns wonder to the margins of our lives. He does not ask about the possibility of a desire grounded in wonder as delight. As a consequence, he cannot ask the following questions: Could I take the judgment of the delight that loves without desire as a paradigm of the ethical? Could I encounter the perfections of the other without experiencing them as an index of my lack? Could I embrace beauty without moving to enjoy-to possess- - it?

Irigaray's ethics of sexual difference calls on us to answer these questions affirmatively. The question for me, however, is not whether we should say "yes "but whether and how we can learn to say "yes." Irigaray reads Descartes'discussion of wonder as directing us toward the yes. I read it as a lesson in why we say "no." It is more than a matter of seeing the glass half empty or half full. It is a matter of understanding the Oedipal logic of anxiety; of discerning how we are implicated in it; and of determining how the subterranean promise of Descartes'description of delight in part three of The Passions can be brought to fruition.

Irigaray reads Descartes' wonder for its utopian vision. Taking up her vision, I read Descartes' account of the first passion for its lessons in what must be done for this vision to become real. For me, the lessons are these: (1) we must disengage wonder from anxiety; (2) we must not only learn to value the yes of uncertainty - the yes that welcomes the unknown, the surprise, the other-we must learn to prefer it to the yes (of certainty) grounded in the no; and (3) instead of allowing desire to establish the meaning and value of wonder we must insist that wonder inform desire. Taking up these lessons, we are confronted with the task of transforming our fear of chance into an embrace of the event. 
There is a sense in which nineteenth- and twentieth-century developments in phenomenology, existentialism, and feminism may be read as engaged in the task of transvaluating Descartes' first passion into Irigaray's wonder. The phenomenological epochè which asks us to disengage from the assumptions of everyday life, not in order to distance ourselves from the sensual but in order to pay closer attention to it; and the existential reformulation of intentionality which refuses the disengagement of the epochè in order to more fully engage phenomenological attentiveness, may be read as steps on the road to Irigaray's wonder. They may be read as moves to ground philosophy in the yes rather than the no.

Simone de Beauvoir's reformulation of intentionality is crucial in this movement. With Beauvoir intentionality becomes ambiguous. It is described as moving between two moments, a moment of disclosure and a moment of appropriation. Each of these moments embodies a distinct attitude toward being. As distinct, however, these moments and their moods are inseparable. Rejecting the logic of the either/or for the logic of ambiguity, Beauvoir's description of intentionality inscribes difference in the field of the bond.

Though she uses the terms "delight" and "joy," Beauvoir's description of the first moment of intentionality recalls us to Descartes'discussions of the first passion and calls us to Irigaray's wonder. But unlike Descartes, who allows Oedipal anxiety to corrupt wonder, Beauvoir preserves wonder's place. According to Beauvoir, "There is an original type of attachment to being ... which is the relationship " wanting to disclose being" (Beauvoir, Ethics 12). Beauvoir distinguishes this bond to the becoming of being from a subsequent moment and relationship to being which she calls "wanting to be" and which she describes as the desire to appropriate. Just as Descartes, Beauvoir notes that we are not content to remain in, or cannot sustain, that moment she calls "disclosure" and he "wonder." Descartes says that we are moved to judgment, that we are moved to possess what appears through the passions of love. Beauvoir agrees with him, but she is also clearer about this movement. These judgments - this love - are the mark of anxiety. And whereas Descartes validates and endorses this flight from the surprises and uncertainties of wonder for the securities and certainties of science and the judgments good and bad, Beauvoir embraces the desire to disclose being and refuses to privilege the desires of judgment and possession. She validates the inevitability of uncertainty. Identifying the judgments 
good and bad, true and false as attempts to appropriate the world, she tells us that these attempts, though necessary, are also necessarily fragile. Ultimately the attempt to appropriate fails. "I cannot," Beauvoir writes, "appropriate the snow field where I slide. It remains foreign, forbidden ..." (Ethics 12).

What is most important in Beauvoir's account of this inevitable failure, however, is this: rather than marking it as a sign of our lack and identifying it with the mood of mourning, she aligns it with the moods of joy and delight. In her words: "I take delight in this every effort toward an impossible possession" (Ethics 12). Now desire is radically refigured. It is not appropriation that brings joy, but its impossibility. It is not by enclosing the world within my sphere of influence but in encountering it as foreign and forbidden that $I$ experience joy. Surprising freedoms are not the source of fear or cowardice. They elicit my delight. This delight does not threaten to infect me with the disease of blind curiosity.

Following Beauvoir, I discover that as wonder lures me to love, the desire to possess the other, the failure of love, the impossibility of possessing the other's freedom return me to wonder. I learn that it is the failure of my desire that makes me human; for in acknowledging both my desire and its failure, I situate myself as meaning-giver of the world within the mood of wonder. As a meaninggiver who must fail at becoming the law I recognize my bond with wonder, the passion that binds me to the limits of the law. Returned to the joy of this excess, I will not be content to remain with its delights. But I do not repudiate them. Without situating myself as a stranger in the world (Camus) I remember that I am bound to a world that is not mine.

With Beauvoir, Descartes' structure of the passions is challenged. Wonder, the passion that is not yet the desire to own or control, remains the first passion. It is not, however, appropriated by the utilitarian ethics of good and bad or the desires of love and hate. In Beauvoir's schema this ethics and these desires are recognized as secondary and subordinate. Instead of being told to outgrow wonder, we learn how we are continually returned to it and that this return is filled with delight. With Beauvoir, finitude- understood as the failure to be God, the inability to control the real, and the impossibility of reducing the world to the category of the useful--is the source of joy not anxiety. Wonder, our response to the surprise of the new, the 
unforeseen and the unexpected, is now understood as that passion that alerts us to the fact that we are neither alone in nor in control of the world.

In calling on us to follow the delight of wonder, Beauvoir does not call us to an ethics of sexual difference. From her point of view, such an ethics bifurcates the ambiguity that guarantees the circulation of desire between the delight of wonder and the drive to be. It undermines the relationship between ethics and politics. But if we focus on the quarrel between Beauvoir and Irigaray, we lose sight of their genealogical relationship and miss the point that however significant that quarrel it is less important than the fact that Descartes' wonder becomes available to/for Irigaray's ethics of sexual difference through Beauvoir's mediation. In linking her ethics of sexual difference to the father of wonder without reference to the woman who drove the anxiety out of wonder so that it could become the place of delight and the site of the erotic event, Irigaray neglects her own maternal lineage. This neglect has its consequences.

Irigaray calls us to the question of sexual difference. It is, she insists, the crucial question of our age. In raising the question of the other and privileging one particular form of otherness, Irigaray's ethics of sexual difference presumes that we know how to properly form the question of the other, for only on that condition can we understand why sexual rather than racial or class difference is the crucial question of our age. We need to go through Beauvoir for this understanding. In attending to the way the Other as an historically constituted site of exploitation has been the site of rebellion and revolution for all others except women, The Second Sex allows us to see how privileging the question of sexual difference opens us out to rather than closes us off from other questions of difference, otherness, and exploitation.

By attending to the ways in which Irigaray's turn to Descartes requires the mediation of Beauvoir, I do not intend to reduce Irigaray to an echo of Beauvoir. Genealogical relationships are transformative not repetitive. If Irigaray must take up Beauvoir's descriptions of the "is" of intentionality's joy and delight to save Descartes' wonder from its Oedipal anxieties, Irigaray also transforms Beauvoir's phenomenological "is" of the first intentional moment into an ethical imperative which insists on the "ought" of that joy Descartes called "wonder." While paying her debt to Descartes, Irigaray ignored Beauvoir's gift. Is this why Beauvoir refused her friendship? 
From a theoretical perspective, Irigaray's An Ethics of Sexual Difference reads the philosophical tradition for its other voice. From a practical perspective, it provides the necessary ethical foundation for a sustainable politics of sexual equity. Feminist theory has taught us that the theoretical and the practical are tethered. A theory that insists that proper sublimation requires giving the mother her proper place must enact its theoretical requirements. If it speaks of the mother by returning to the father, the specter of the father will haunt it. It will return us to the place we hoped to leave. Hoping to escape the reign of violence, for example, we may find ourselves seduced into giving it new territory. If we fail to work Descartes' concept of wonder through Beauvoir's concept of ambiguity, we may not hear Bataille's warning about the violence embedded in intimacy and unleashed by its excess. In attacking the injustices of the ordered world of reason and returning to wonder to free ourselves from that world's grip, we may forget the ways in which this world protects us from the excess of wonder's ethic of the useless. Although the concept of the useless offers an antidote to the nihilisms of an exchange economy, in directing us to the useless consumption "which I am intimately" it may also release a violence without limit (Bataille 58-59).

In alerting us to the failure of the desire to be and in refusing to treat this failure as a loss, Beauvoir's description of our two-fold intentionality also alerts us to the limits of wonder. She does not formulate these limits in Bataille's terms, perhaps because Bataille misunderstands the intimacy of wonder or because Beauvoir too is guilty of idealizing the erotic. Either way the crucial point remains that the paradigm of ambiguity alerts us to the importance of probing Bataille's warnings and provides us with a theoretical structure for doing so. It saves us from the trap of inverting the relationship between wonder and desire.

To ask Irigaray to go through Beauvoir is not to ask her to agree with Beauvoir. Rather it is to encourage Irigaray to take a closer look at wonder's relationship to desire to prevent her ethics of sexual difference from unreflectively calling up the anxieties of wonder, the violent excesses of wonder, or the politics of Oedipus. There is no guarantee that going through Beauvoir will save Irigaray's ethics of sexual difference from its difficulties. But in a world without 
guarantees, paying one's genealogical debts is the first gesture of friendship and a crucial step toward enacting an ethics of sexual difference.

George Mason University

\section{Debra Bergoffen}

\section{Works Cited}

Bataille, George. The Accursed Share, Vol. 1: Consumption. Trans. Robert Hurley. New York: Zone Books, 1988.

Bauer, Nancy. Simone de Beauvoir: Philosophy and Feminism. New York: Columbia University Press, 2001.

Beauvoir, Simone de. The Ethics of Ambiguity. Trans. Bernard Fechtman. New York: Philosophical Library, 1948.

---. The Second Sex. Trans. H.M. Parshley. New York: Vintage,1989. Descartes, Rene. The Passions of the Soul. Trans. Elizabeth S. Haldane and G.R. T. Ross. The Philosophical Works of Descartes. Vol. 1. London: Cambridge University Press, 1969. 329-427.

Irigaray, Luce. An Ethics of Sexual Difference. Trans. Carolyn Burke and Gillian C Gill. Ithaca, N.Y.: Cornell University Press, 1993.

---. je, tu, nous: Toward a Culture of Difference. Trans. Alison Martin. New York: Routledge, 1993.

---. Speculum of the Other Woman. Trans. Gillian C. Gill. Ithaca, N.Y.: Cornell University Press, 1985.

Simons, Margaret A. Beauvoir and The Second Sex: Feminism, Race and The Origins of Existentialism. New York: Roman and Littlefield, 1999. 